\title{
A Discussion on the Innovative Teaching System of Business English in Higher Vocational Education
}

\author{
Hong-xia ZHAO ${ }^{1, a, *}$ \\ ${ }^{1} 100$, Xiabo Road, Ganjingzi District, Dalian, Liaoning Province, China \\ a1003967953@qq.com
}

Keywords: Innovation, Teaching system, Business English.

\begin{abstract}
Taking the cultivation of Business English major as the research object, this paper mainly discusses the effective ways and channels to train students to gain the service capabilities concerning foreign business affairs and professional qualities. On the principle of systematic construction, highlighting features and achievements, emphasizing quality, higher vocational colleges should carry out a series of undertakings to overcome the long-standing disadvantages of Business English teaching, making the breakthrough in work-integrated learning, enhancing professional abilities and professional qualities.
\end{abstract}

\section{Introduction}

As for the Business English major in higher vocational colleges, generally speaking, there four bottlenecks for their development.

First, the graduates of Business English major have broad and extensive employment opportunities, without uncertain employment orientation. Post competency and comprehensive quantities of them couldn't fit in the needs of economic globalization and upgrade of industry.

Second, the curriculum of Business English in higher vocational colleges lacks specific pertinence; the teaching content is not up-to-date, teaching theory and teaching methods lag behind, evaluation for curriculum is not diversified.

Third, it is hard to implement the combination of work and learning, since off-campus internship posts scatter and lack foreign languages context. It is quite hard for students to come into contact with the whole working process in foreign-related enterprises, resulting from the absence of scientific, systematic practical teaching system.

Forth, the teaching staff of Business English major in higher vocational colleges is typical of single structure in knowledge and professional qualities, insufficient in industry experience and inadequate international vision.

\section{The Targets for Business English to Build}

\section{To Build the Teaching System Featuring Both Capabilities and Qualities, Realizing the Talents Cultivation Target Effectively}

Focusing on channels and methods of cultivating foreign -related service capabilities of students and professional qualities, we are aiming at working out a plan to optimize the previous innovation that is not in a systematic manner, resulting in the single path, benefiting only small portion of students. Efforts should be made to undertake a 
systematic innovation in class-teaching, teaching methods, teaching staff, training and so on to finally achieve target of cultivating students effectively.

To Design the Escalating Structure of Practical Teaching Model, Cracking the Difficulties of Work-integrated Learning for Business English

It is suggested to build $t$ an escalating structure of practical teaching model, transferring the previous isolated basic language training and business skills training into progressive systematic training with an aim to optimize the practical teaching, endow students to experience the virtual situation, business stimulation and even real working experience.

\section{To Apply the International Vocational Education Theory, Creating Multiple Evaluations Featuring Process Evaluation}

Drawing lessons from TAFE in evaluation, it is suggested to formulate unified criteria and evaluation guidance book for students. In line with unit task, teachers ascertain the requirements for language, skills and qualities, and practice the multiple evaluations based on vocational post capabilities. Under this guidance, teachers and students have clear framework in teaching and learning respectively, which could ease the international cooperation difficulties in localization.

\section{Three Phases to Implement Innovation of Business English}

\section{Research and Argumentation}

The first phase is mainly to clarify the chief problems in talents cultivation of Business English. Through researches and argumentations, efforts should be made to further define the target of talents cultivation of Business English.

\section{Implementation}

The second phase is mainly to focuses on the new talents cultivation program and teaching system, characterizing both capabilities and qualities. Various programs will be carried out, such as textbooks compiling, teaching methods seminars, and evaluation refinement, setting-up of in-campus and out-campus training bases, and teaching staff training.

\section{Reflection and Popularization}

In third phase, efforts should made to refine teaching innovation, curriculum with characteristic of equal importance in both capabilities and qualities, practical teaching mode of escalating structure via speeches and training and share the fruits with counterparts in different colleges.

\section{The Content and Measures}

\section{To Establish the Teaching Theory in Co-cultivation of Capabilities and Qualities}

Adhering to the basic principles of cultivation orientation and capability focus, it is suggested to adjust the talents cultivation target based on the talents need of local enterprises to build the new teaching system, featuring foreign-related business service capabilities and professional qualities. 


\section{To Build Model-based Curriculum System Emphasizing Vocation Post Ability and Comprehensive Quality}

Based on talents needs of enterprise, teaching staff of Business English should conduct the analysis on the employment posts of graduates and professional certificate, and then design the curriculum system, featuring essential qualities and professional qualities. This curriculum covers four modules, namely English application, foreign trade business, business communication, business management. [1]

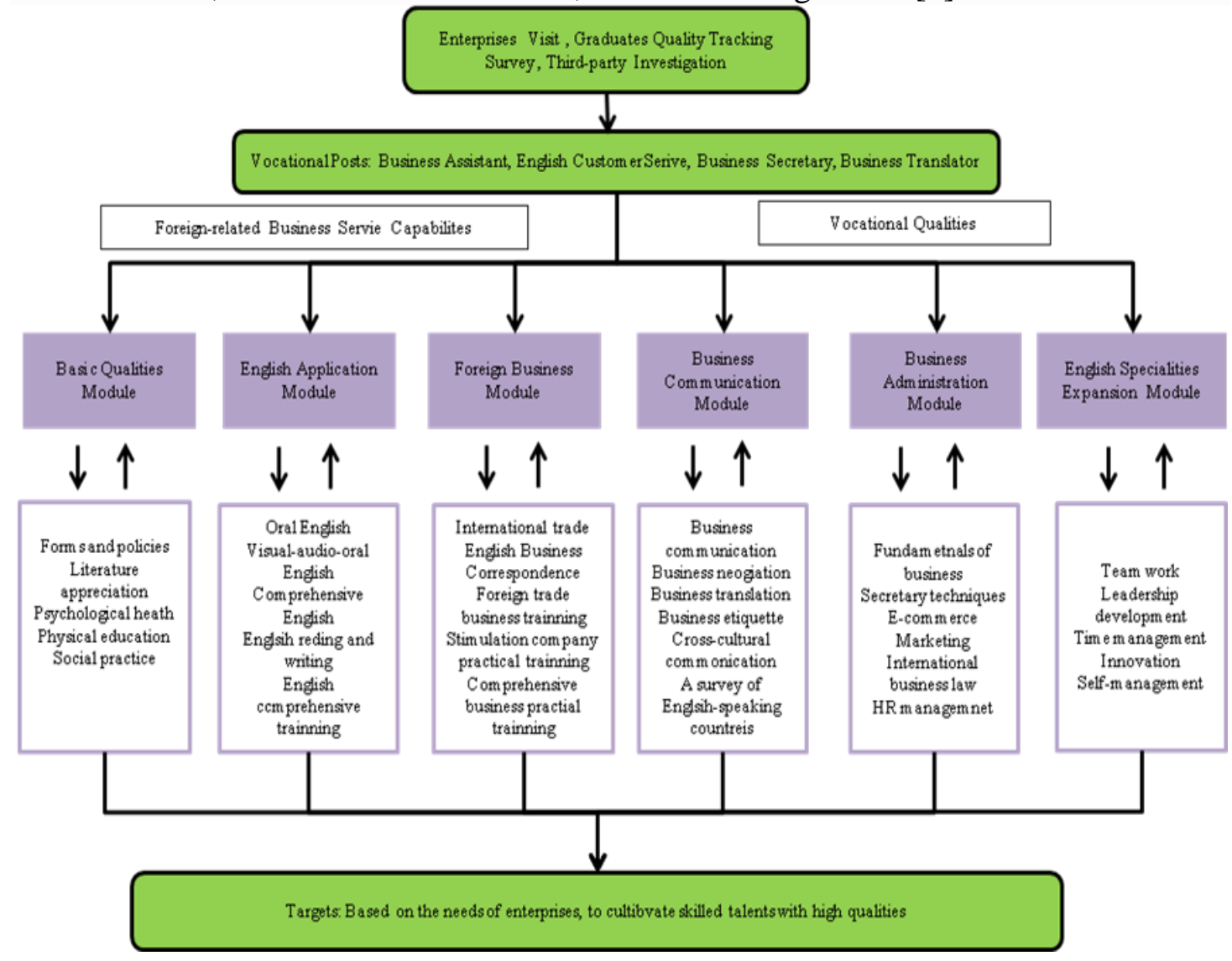

Figure 1. Teaching Curriculum of Business English

\section{To Apply the Modern Informational Teaching Means, Innovating Teaching Methods, Realizing Mobile Teaching}

Business English teachers should make a good use of campus WIFI and teaching platforms to realize the virtual situation teaching and mobile learning. Only in this way, can we effectively combine the in-class learning and out-class on-line learning, enabling students get access to on-line learning resources anytime and anywhere, which could greatly increase the students' passion to learn, cultivate students' habit of self-study and finally make up the insufficiencies of in-class teaching.

\section{To Establish the Escalating Structure of Practical Teaching Model}

Based on the in-campus and out-campus training bases, it is necessary to design the escalating structure of practical teaching model, ranging from phase 1 to phase 4 realizing the cultivation process in the fields of virtual experience, real vocational posts. 


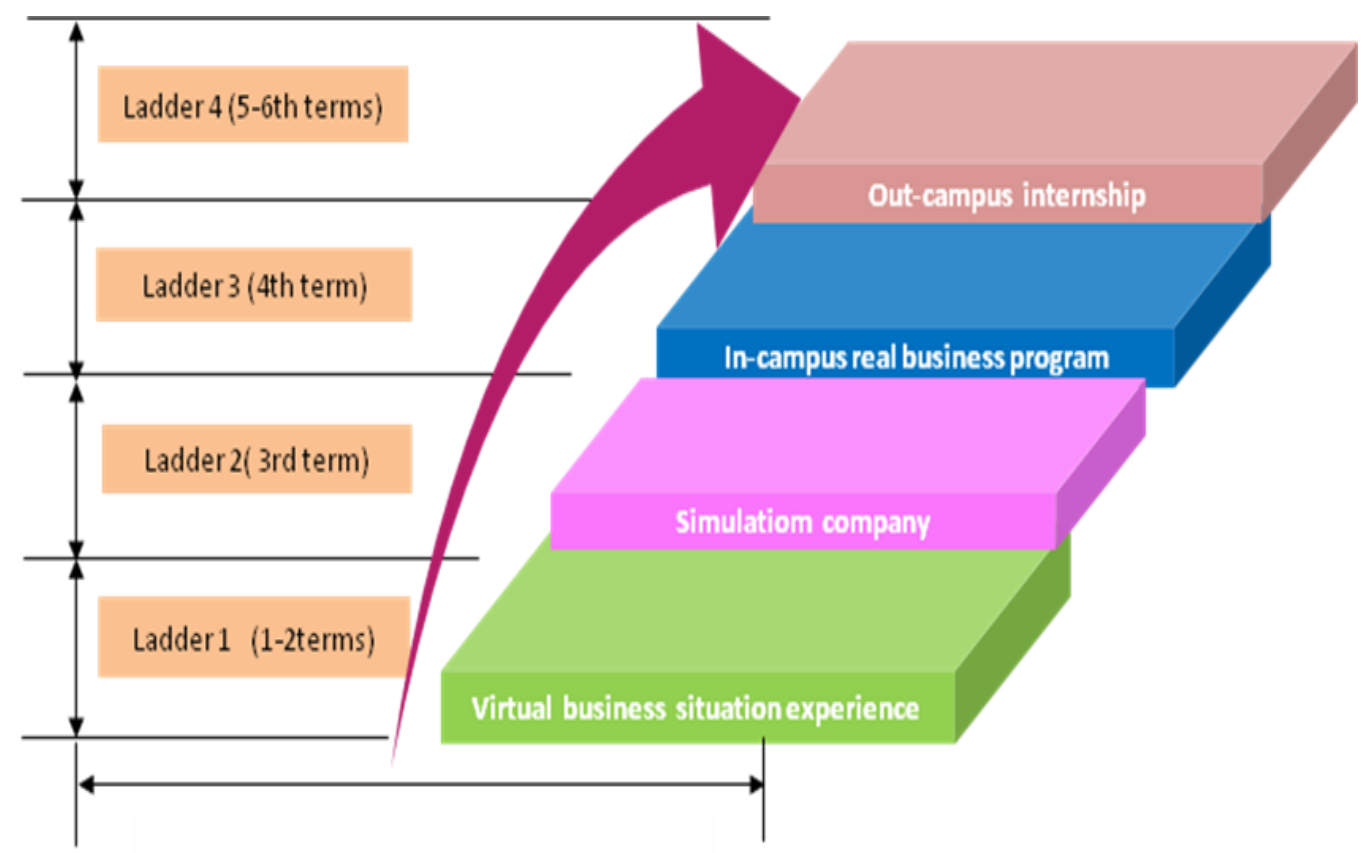

Figure 2. The escalating structure of practical teaching model

\section{Ladder 1: Virtual Business Situation Experience Practical Training}

It is arranged in the first and second terms and conducted in the in-campus training bases via IBET Trade training simulation training system. Students can play various parties concerned in the process of import and export in comply with the practical training plan, making the simulated trade situation. The trade situations cover office work, business travel, client research, companies and products, marketing, meeting, recruiting, trade fairs, enquiries and offers, counter offer and orders, packing and shipment, payment, insurance, conclusion of business, trademarks, patent and intellectual rights, complaints, claims and settlement.

This training program can be divided into 7 roles, namely administrator, teacher, exporter, importer, factory, business center and bank. Each role has its own responsibilities. As for administrators, they are responsible for administrating teaching materials of all classes, teachers' handouts and all the notices. As for teachers, they are responsible for setting up the practical training plan, allocating the role for students, publishing the messages, adjusting the cost and sale price of products, exchange rate, premium, freight rates. They are also responsible for designing the criteria and put the real-time monitoring on students' operation into effect. As for students, they can take the roles of exporter, importer, factory and bank and fulfill their own daily work in the workplace. [2]

\section{Ladder 2: Simulation Company Practical Training}

It is suggested to be arranged in the third and fourth terms and undertook in the in-campus training bases. Relying on international trade training system, teachers help students set up simulation companies, creating the virtual simulation environment and conducting a serious of international trade activities.

The practical training of Simulation Company follows the principle of project teaching method, designs the training courses, and break down the project into several tasks. In this project, students, under the guidance of teachers, set up a simulation company and can select their posts according to their own will and are able to conduct 
the operating tasks of a company. In this training project, they could voluntarily select the roles of CEO, sales person, purchase person, accountant and so on.

Though simulation, students can finish the task of enquiries and offers, counter offer and orders, packing and shipment, payment, insurance, conclusion of business, complaints, claims and settlement. Only in this way, can they understand and experience the working tasks, responsibilities of various posts and the interaction of function departments. Once the simulation succeeds, students can transfer this training program into real business program, reducing the risk of setting up a business. More importantly, students can promote the practical operating capability; enhance the "real" working experience, elevate the professional qualities.

\section{Ladder 3: In-campus Real Business Programs Training}

It is suggested to be arranged in the fourth term for 8 weeks. Real Business programs will be carried out by students under the guidance of teachers. Colleges could introduce some production and service of cooperating company into campus. For example, colleges can carry out cooperation with translation companies by providing classroom and students in a way of setting up translation workshop, and students can finish the translation task from the customers. Beside, colleges could cooperate with the international trading companies in the form of teaching company to carry out the international business. Colleges, companies and students can make a good use of their own advantages in the fields of order receiving, documentary, on-line marketing, realizing the all-win for the parties involved.

\section{Ladder 4: Out-campus Internship}

It is suggested to be arranged in the $5^{\text {th }}$ and $6^{\text {th }}$ terms in the trade fairs, 5-star hotels, and foreign trading companies, increasing the students' sense of responsibilities. Colleges can organize the job fairs, sign the agreements with them, and allocate the students into these companies to undertake the posts that they might take after internship. Though this some 6-month internship, students are required to write the report and journal, enhancing the deep understanding of their foreign language and lading the solid foundation for their business language learning and future work.

Enterprises should provide the posts for students and cooperate with teachers in safe education training. Students take up the real tasks in the bio-identities of both students and prospective employees. During this training, students should master the basic operating skills, comprehend the enterprise culture, and develop their professional qualities and business ethics. Under the guidance of teachers of college and masters of enterprises, students should finish the internship journal, internship report, finish oral defense for their reports.

This training practice realizes three targets. First, students undertake the identity of prospective employees in the enterprises. Second, the intern complies with the employment post. That is to say, after the internship, students naturally become the employees. Third, the intern is also considered as the probation. To sum up, this out-campus training features employment-centered, realizing the connection between talents cultivated by the colleges and the one needed by the enterprises. 


\section{Conclusion}

The innovative teaching system of business English will have a lead in higher vocational education and play a demonstration effect to the counterparts domestically, which obtains the great promoting value.

\section{References}

[1] Han $\mathrm{Wu}$, The Practice of Innovative Teaching of Business English in Higher Vocational Colleges, Chinese Vocational and Technical Education, J.(2015) 65-67.

[2] Li Gan, A Discussion on Enterprise-College Cooperation of Business English of Higher Vocational Colleges, Chinese Vocational and Technical Education, J.(2013) 80-82. 